Vol 2 No 1 Juli 2021

Jurnal AlphaEuclidEdu

Received:21/10/2020; Resived:04/04/2021; Accepted:06/07/2021

\title{
PEMBELAJARAN MATEMATIKA MENGGUNAKAN LEMBAR KERJA PESERTA DIDIK (LKPD) BERBENTUK KOMIK
}

\author{
${ }^{1}$ Suhartati, ${ }^{2}$ Yulis Jamiah, ${ }^{3}$ Silvia Sayu \\ ${ }^{1,2,3}$ Pendidikan Matematika FKIP Universitas Tanjungpura Pontianak \\ *Email: official.suhartati@gmail.com
}

\begin{abstract}
This research aims to know the effectiveness of LKPD from comic in mathematics teaching a algebra's subject for students of SMA Negeri 3 Pontianak. This research is classified as a pre-experimental in form of one shot case study design. The population of this research were students of eleven grade science program, and the samples is 1 class of students in eleven grade science program. The sample were selected by conducting purposive sampling. The revenue of data analysis point out that the learning activity was very active with the average student learning activities obtained by $89.35 \%$, the study result was reached. Student gave a great feedback, the implementation of learning management by teachers in learning mathematics was classified as 'very good'. Based on the research findings that four cathegories of effectiveness was reached, therefore the application of LKPD from comic was effective in mathematic teaching a algebra materials to the students grade XI science 2 of SMA Negeri 3 Pontianak.
\end{abstract}

Keywords: Effectiveness, LKPD, Comic

\section{Pendahuluan}

Lembar Kerja Siswa (LKS) menjadi perangkat yang umumnya digunakan dalam pembelajaran. Penamaan LKS di Kurikulum 2013 revisi adalah Lembar Kerja Peserta Didik (LKPD) yang merupakan contoh media pembelajaran yang dapat membantu peserta didik maupun guru dalam proses pembelajaran, termasuk untuk meningkatkan keaktifan peserta didik dan keefektifan pembelajaran (Nurdin dan Adriantoni, 2016:111). Keefektifan belajar peserta didik juga bisa ditingkatkan dengan cara memberikan kesempatan peserta didik untuk menyelesaikan lembar kerja secara mandiri atau kelompok (Sumiati, 2007:171). Achmadi (dalam Nurdin dan Adriantoni, 2016:112) memaparkan bahwa kegunaan LKPD adalah untuk membantu peserta didik mengembangkan konsep dan keterampilan proses, memperoleh informasi tentang yang dipelajari, serta menjadi pedoman bagi guru dan peserta didik dalam pembelajaran.

Banyaknya manfaat LKPD tersebut menjadikannya media yang penting dalam sebuah pembelajaran. Namun kenyataannya, tak sedikit guru melupakan pengajaran dengan bantuan LKPD. Hasil pengamatan saat mengikuti Program Pengalaman Lapangan (PPL) di SMAN 3 Pontianak, tampak rata-rata guru Matematika mengajar dengan cara konvensional dan jarang sekali menggunakan LKPD sebagai media untuk menunjang pembelajaran. Sehingga peserta didik tampak kurang aktif dalam berdiskusi dan bertanya. Padahal, peserta didik tampak menyukai LKPD yang dibuat oleh penulis saat mengajar materi Statistika di Kelas XI. Oleh karena itu, selain menjadi media yang penting untuk membuat peserta didik aktif, LKPD juga menarik fokus dan perhatian peserta didik saat pembelajaran. Setelah wawancara dengan guru Matematika di SMAN 3 Pontianak, diketahui bahwa LKPD yang sering digunakan di Sekolah berupa buku 
dari sebuah penerbit yang isinya cenderung singkat sehingga peserta didik susah untuk memahami maksud dari LKPD tersebut. Hal ini bertentangan dengan ciri-ciri LKPD yang baik, yaitu memenuhi syarat didaktik, konstruksi, dan teknik (Darmodjo, dalam Widjajanti, 2008:2-4). Syarat didaktik mengharuskan LKPD bersifat universal yang dapat digunakan peserta didik yang lamban maupun pandai, menitikberatkan pada proses menemukan konsep, ada variasi stimulus melalui berbagai kegiatan dan media, serta diutamakan untuk mengembangkan kemampuan komunikasi sosial, emosional, moral, serta keindahan. Terkait penggunaan bahasa, kata dan kalimat, serta tingkat kesukaran dan kejelasan dalam LKPD menjadi bagian dari syarat konstruksi. Sedangkan terkait tulisan, gambar, serta tampilan LKPD diatur dalam syarat teknis.

Contoh LKPD yang dapat diterapkan dalam pembelajaran guna menarik hati peserta didik dan tujuan pembelajaran tercapai adalah dengan menggunakan LKPD berbentuk Komik. Komik merupakan media yang dapat menarik minat peserta didik karena gambar maupun dialog dari para tokohnya bisa dinikmati oleh peserta didik. Jika disajikan secara menarik, komik dapat menjadi media sekaligus penghibur bagi peserta didik dalam pembelajaran.

Komik yang dikemas dengan menarik akan menjadi media yang sangat baik bagi peserta didik, sehingga mereka akan terhibur selama proses pembelajaran. Melalui gambar kartun, sebuah informasi bisa menjadi sebuah pesan yang efektif dengan bantuan pengamatan (Sengüla, 2010:5442); (Jamiah, 2020). Oleh karena itu, kartun juga sedikit banyaknya berdampak pada dunia pendidikan yaitu melalui fungsi penginformasian. Göker (dalam Sengüla, 2010:5442); (Haran et al., 2019) juga memaparkan bahwa humor kartun wajah yang indah dari desain kartun itu seperti obat dilapisi cokelat untuk peserta didik.

Kelebihan media komik untuk kegiatan pembelajaran menurut Demetrulias (dalam Sengüla, 2010:5442) adalah untuk dikembangkannya kemampuan membaca, kosa kata, keterampilan berpikir, pemecahan masalah, menyelesaikan konflik, motivasi, serta dimunculkannya pengetahuan dan ide-ide ilmiah.

LKPD berbentuk komik juga dapat meningkatkan pengetahuan kognitif. Terlihat dari penelitian terdahulu oleh Utomo (2012) yang mengembangkan sebuah LKPD berbentuk komik. Hasil ujinya dinyatakan bahwa lembaran kerja berbentuk ilustrasi komik yang digunakannya efektif untuk meningkatkan hasil belajar karena adanya perbedaan rata-rata hasil posttest $(80,83)$ dan pretest $(47)$. Penelitian Windayana, dkk (2013:102) juga mengungkapkan bahwa LKPD komiknya berhasil membuat prestasi belajar peserta didik meningkat karena rerata nilai posttest kelompok yang diberikan perlakuan lebih besar $(80,94)$ daripada kelompok kontrol $(67,03)$. Sikap belajar peserta didik yang diberi LKPD bentuk komik juga lebih baik dibandingkan yang belajarnya biasa saja. Peserta didik tampak antusias dan aktif ketika memaparkan cerita dalam lembar kerja, bekerja secara berkelompok, serta menyelesaikan tahapan lembar kerja terkait konsep dan materi pembelajaran. Penelitian pengembangan LKPD bentuk komik juga dilakukan oleh Susanti (2016:201) yang hasilnya menunjukkan bahwa persentase 
respons peserta didik secara klasikal mencapai 71,6 \% dan tergolong kriteria yang baik, dengan kata lain respons peserta didik terhadap LKPD dan komik sangat positif.

Materi Aljabar selalu ada di setiap jenjang pendidikan. Aljabar di tingkat SMA/MA adalah materi yang di keluarkan dalam Ujian Nasional (UN). Namun, hasil persentase penguasaan materi UN Matematika SMA/MA materi Aljabar masih tergolong rendah. Tahun ajaran 2015/2016, persentase hasil penguasaan materi Aljabar UN SMA/MA tingkat Kab/Kota Pontianak sebesar 72,43\%, tingkat Provinsi Kalbar sebesar 57,77\%, dan tingkat Nasional sebesar 59,54\%. Persentase tergolong rendah karena aljabar yang sifatnya abstrak dan mengandung banyak variabel. Serta diperkuat pula dengan fakta bahwa selama ini aljabar biasanya diajarkan dengan simbolik variabel sehingga peserta didik sulit untuk memahami materi dan menurunkan minatnya dalam belajar.

Materi Aljabar akan mudah dipahami oleh peserta didik apabila guru dapat membuat inovasi pembelajaran yang berbeda dari biasanya. Contohnya menggunakan LKPD berbentuk komik karena bisa mengefektifkan pembelajaran materi Aljabar. Guru dapat membuat simbol-simbol, ikon-ikon, dan gambar-gambar yang dapat menggantikan peran notasi yang berhubungan dengan Aljabar menggunakan komik. Hal ini senada dengan teori belajar yang dipaparkan Bruner (dalam Pitadjeng, 2015:39) bahwa peserta didik akan melalui tahapan sebanyak tiga tahapan dalam belajar, yaitu tahap enaktif, ikonik, dan simbolik. Pada tahap ikonik, anak-anak dapat memanipulasi menggunakan gambar objek-objek yang konkrit. Simbol-simbol akan bisa dimanipulasi langsung oleh anak umur delapan tahun ke atas pada tahap simbolik, dan tidak lagi ada kaitannya dengan objek-objek.

\section{Metode Penelitian}

Metode penelitian dalam penelitian ini adalah penelitian eksperimen. Jenis desain eksperimennya adalah pre-eksperimental designs serta jenis bentuk desainnya adalah one shot case study design. Jenis desain ini dipilih karena sebuah tujuan sederhana yaitu ingin mengetahui efektivitas pembelajaran Matematika menggunakan LKPD berbentuk komik.

Penelitian dilaksanakan di SMA Negeri 3 Pontianak dengan populasinya adalah peserta didik SMAN 3 Pontianak kelas XI program IPA. Karena pertimbangan tertentu, teknik untuk mengambil sampelnya adalah purposive sampling (Sugiyono, 2016:124). Berdasarkan pertimbangan peneliti dan guru Matematika kelas XI SMAN 3 Pontianak, sampel yang diambil adalah satu kelas sebagai kelompok yang diberikan perlakuan, yaitu Kelas XI IPA 2. Materi yang dipilih adalah materi aljabar, terkhusus operasi matriks.

Prosedur penelitian terdiri dari tahap persiapan, pelaksanaan, dan tahap akhir.

\section{Tahap Persiapan Penelitian}

Persiapan yang dilakukan adalah: (1) membuat RPP dan LKPD berbentuk komik, soal tes hasil belajar, lembar pengamatan aktivitas belajar peserta didik, angket respons peserta didik, dan lembar keterlaksanaan pengelolaan pembelajaran oleh guru; (2) melakukan seminar desain penelitian; (3) merevisi desain penelitian; (4) memvalidasi 
perangkat dan instrumen penelitian; (5) merevisi hasil validasi; (6) mengurus surat izin untuk uji coba soal dan penelitian; (7) melakukan uji coba soal tes hasil belajar; (8) menganalisis hasil uji coba soal.

\section{Tahap Pelaksanaan Penelitian}

Tahap pelaksanaan yang dilaksanakan adalah: (1) melaksanakan proses pembelajaran menggunakan LKPD berbentuk komik; (2) mengamati dan mengisi lembar observasi aktivitas peserta didik serta aktivitas guru (peneliti) saat mengelola pelajaran oleh para observer saat kegiatan belajar mengajar berlangsung; (3) memberikan tes hasil belajar pada sampel penelitian; (4) memberikan angket respons kepada sampel penelitian; (5) mengolah data hasil penelitian yang diperoleh.

\section{Tahap Akhir (Analisis Data)}

Tahap akhir yang dilakukan adalah: (1) memaparkan hasil pengolahan data dan menyimpulkannya; (2) menyusun laporan.

\section{Pembuatan Perangkat Pembelajaran}

Perangkat pembelajaran (RPP dan LKPD berbentuk komik) dibuat serta disesuaikan dengan RPP Kurikulum 2013 revisi yang berlaku saat ini dan dibuat sebanyak dua buah untuk pertemuan ke-1 dan ke-2.

Lembar Kerja Peserta Didik (LKPD) berbentuk komik dibuat sendiri oleh peneliti dengan langkah-langkah pembuatannya, yaitu: (1) merancang secara umum konsep LKPD yang sesuai dengan materi operasi aljabar dan disesuaikan dengan RPP yang telah dibuat; (2) menggambar komik secara manual di atas kertas HVS putih menggunakan pensil, kemudian ditebalkan dengan spidol hitam. Penggambaran dilakukan sendiri oleh peneliti dan semua tokoh yang dibuat adalah hasil kreativitas peneliti; (3) menyimpan gambar dalam bentuk softfile dengan format jpeg kemudian di tambahkan percakapan antar tokoh, informasi pembelajaran, soal-soal, serta diberi pewarnaan dengan menggunakan aplikasi Adobe Photoshop CC 2015; (4) gambar disimpan dalam bentuk softfile dengan format jpeg.

RPP dan LKPD juga melalui tahap validasi yang dilakukan oleh satu dosen matematika FKIP Untan, satu guru matematika SMA Negeri 3 Pontianak, dan satu guru matematika SMA Negeri 1 Kakap.

\section{Teknik dan Alat Pengumpulan Data}

Teknik pengukuran, observasi langsung, serta komunikasi tidak langsung digunakan dalam penelitian ini. Observasi yang dilakukan adalah observasi keterlaksanaan pengelolaan pembelajaran oleh guru dan aktivitas belajar peserta didik saat diberikan pembelajaran. Observasi dilakukan dari awal guru membuka hingga menutup pembelajaran. Pengamat keterlaksanaan pengelolaan pembelajaran oleh guru (peneliti) adalah guru Matematika Wajib kelas XI SMAN 3 Pontianak dan pengamat aktivitas belajar peserta didik adalah dua orang mahasiswa Pendidikan Matematika.

Teknik komunikasi tidak langsung dilakukan dengan menggunakan angket atau kuisioner sebagai alat pengumpul data (Nawawi, 2015:117-118), yaitu angket respons peserta didik terhadap media LKPD berbentuk komik. Angket diberikan setelah peserta didik mendapatkan pembelajaran menggunakan LKPD berbentuk komik dengan 
maksud untuk mendapatkan data tentang respons peserta didik terhadap media LKPD berbentuk komik.

Alat pengumpulan data atau instrumen penelitian ini berupa tes hasil belajar, lembar observasi aktivitas belajar peserta didik, angket respons peserta didik, dan lembar observasi keterlaksanaan pengelolaan pembelajaran oleh guru. Tes uraian dipilih sebagai jenis tes hasil belajar. Soal tes berjumlah lima buah dan sebelumnya telah dibuat kisi-kisinya, butir soal, dihitung validitas, reliabilitas, indeks kesukaran soal, serta daya pembeda soalnya.

Validitas isi dan butir digunakan dalam penelitian ini. Validitas isi digunakan dengan maksud untuk melihat kesesuaian antara tujuan pembelajaran, indikator pencapaian kompetensi, materi, kisi-kisi soal, dan soal. Setelah divaliditas isi, tes kemudian diuji coba, barulah divaliditas butir setiap item soal dengan maksud untuk mengetahui butir-butir soal tes yang tidak layak ditinjau dari validitasnya. Hasil validitas item tes hasil belajar dalam penelitian ini adalah semua item tes memiliki validitas yang baik karena harga korelasi tiap item di atas 0,30 .

Rumus Alpha digunakan untuk menghitung reliabilitas tes hasil belajar (Sudijono, 2012:208). Hasil perhitungan menunjukkan bahwa koefisien reliabilitas sebesar 0,621 dan tergolong dalam kriteria reliabilitas yang tinggi. Selanjutnya tingkat kesukaran soal dan daya pembeda dihitung dan hasilnya menunjukan bahwa soal tes nomor satu tergolong dalam soal mudah. Soal nomor dua, tiga, serta empat tegolong dalam soal yang sedang, dan soal nomor lima tergolong dalam soal yang susah. Sedangkan perhitungan daya pembeda soal menunjukan soal nomor satu tingkat kesukaran itemnya tergolong sedang. Soal nomor dua dan tiga tergolong baik sekali, serta soal nomor empat dan lima tergolong baik.

Lembar pengamatan aktivitas belajar peserta didik dan lembar pengamatan keterlaksanaan pengelolaan pembelajaran dibuat secara terstruktur serta disesuaikan dengan RPP yang telah dibuat. Sedangkan angket respons peserta didik yang digunakan adalah angket tertutup yang berisikan pernyataan positif maupun negatif serta menggunakan skala likert dengan pilihan yang disediakan adalah sangat setuju, setuju, tidak setuju, serta sangat tidak setuju (Riduwan, 2015:39). Ketiga instrumen tersebut juga divalidasi isi agar instrumen yang akan digunakan sesuai dengan isi pelajaran yang diberikan dan dapat mengukur indikator yang inigin diukur.

Validator alat pengumpulan data dalam penelitian ini dilakukan oleh seorang dosen pendidikan matematika FKIP Untan, satu guru matematika SMAN 3 Pontianak, dan satu guru matematika SMAN 1 Kakap. Validator memberikan kritik dan saran yang selanjutnya peneliti lakukan revisi pada hasil validasi. Setelah dilakukan perbaikan maka alat pengumpulan data dianggap valid dan siap diujicobakan dan digunakan dalam penelitian. 


\section{Hasil Penelitian dan Pembahasan}

\subsection{Hasil Penelitian}

Penelitian dilakukan sebanyak dua kali pertemuan di kelas XI IPA 2 SMA Negeri 3 Pontianak, dengan jumlah siswa sebanyak 35 orang siswa. Perlakuan penelitian berupa pembelajaran matematika menggunakan LKPD berbentuk komik pada materi Aljabar, khususnya materi Operasi Matriks.

Berdasarkan penelitian yang telah dilakukan, didapatkan data hasil penelitian meliputi: data hasil observasi aktivitas belajar peserta didik, data tes hasil belajar peserta didik, data hasil observasi pengelolaan pembelajaran oleh guru, dan data angket respons peserta didik terhadap pembelajaran Matematika menggunakan LKPD berbentuk komik pada materi Operasi Matriks.

Observasi aktivitas belajar peserta didik dilakukan sebanyak dua kali. Setiap pertemuannya, observer mengamati aktivitas peserta didik selama proses pembelajaran berlangsung. Hasil pengamatan aktivitas belajar peserta didik oleh dua orang observer pada pertemuan ke-1 dan ke-2 dapat dilihat pada tabel 1 sebagai berikut.

Tabel 1. Hasil Pengamatan Aktivitas Belajar Peserta Didik Pertemuan Pertama dan Kedua

\begin{tabular}{|c|c|c|c|c|c|c|c|}
\hline \multirow{3}{*}{ Kategori } & \multirow{3}{*}{ Indikator } & \multirow{2}{*}{\multicolumn{2}{|c|}{$\begin{array}{c}\text { Jumlah } \\
\text { turus }\end{array}$}} & \multicolumn{4}{|c|}{$\%$} \\
\hline & & & & \multicolumn{2}{|c|}{ Per-Indikator } & \multicolumn{2}{|c|}{ Per-Kategori } \\
\hline & & P1 & $\mathbf{P 2}$ & P1 & P2 & P1 & P2 \\
\hline \multirow{4}{*}{$\begin{array}{l}\text { Visual } \\
\text { activities }\end{array}$} & $\begin{array}{l}\text { Memperhatikan guru saat menyampaikan } \\
\text { apersepsi }\end{array}$ & 34 & 32 & 97,1 & 91,4 & \multirow{4}{*}{96,43} & \multirow{4}{*}{87,14} \\
\hline & $\begin{array}{l}\text { Memperhatikan guru saat ditunjukkan } \\
\text { dan dijelaskan cara menggunakan LKPD }\end{array}$ & 35 & 28 & 100,0 & 80,0 & & \\
\hline & $\begin{array}{l}\text { Memperhatikan teman yang } \\
\text { menyampaikan hasil diskusi }\end{array}$ & 31 & 29 & 88,6 & 82,9 & & \\
\hline & $\begin{array}{l}\text { Melihat dan membaca cerita di LKPD } \\
\text { berbentuk komik }\end{array}$ & 35 & 33 & 100,0 & 94,3 & & \\
\hline \multirow{5}{*}{$\begin{array}{l}\text { Oral } \\
\text { activities }\end{array}$} & $\begin{array}{l}\text { Mengajukan pertanyaan kepada } \\
\text { guru/teman }\end{array}$ & 14 & 25 & 40,0 & 71,4 & \multirow{5}{*}{77,71} & \multirow{5}{*}{88,00} \\
\hline & $\begin{array}{l}\text { Memberikan pendapat/jawaban secara } \\
\text { lisan/menanggapi pertanyaan dari guru } \\
\text { saat kegiatan pendahuluan }\end{array}$ & 27 & 31 & 77,1 & 88,6 & & \\
\hline & $\begin{array}{l}\text { Memberikan pendapat/jawaban secara } \\
\text { lisan/menanggapi pertanyaan dari } \\
\text { guru/menanggapi hasil presentasi teman } \\
\text { saat kegiatan inti }\end{array}$ & 26 & 30 & 74,3 & 85,7 & & \\
\hline & $\begin{array}{l}\text { Menjawab salam dari guru saat kegiatan } \\
\text { pendahuluan }\end{array}$ & 35 & 32 & 100,0 & 91,4 & & \\
\hline & $\begin{array}{l}\text { Menjawab salam dari guru saat kegiatan } \\
\text { penutup }\end{array}$ & 34 & 34 & 97,1 & 97,1 & & \\
\hline \multirow{3}{*}{$\begin{array}{l}\text { Listening } \\
\text { activities }\end{array}$} & $\begin{array}{l}\text { Mendengarkan teman sekelompok yang } \\
\text { sedang berbicara }\end{array}$ & 21 & 33 & 60,0 & 94,3 & \multirow{3}{*}{84,76} & \multirow{3}{*}{87,62} \\
\hline & $\begin{array}{l}\text { Mendengarkan guru saat menyampaikan } \\
\text { cara belajar dalam kelompok }\end{array}$ & 35 & 28 & 100,0 & 80,0 & & \\
\hline & $\begin{array}{l}\text { Mendengarkan penjelasan dari } \\
\text { guru/presentasi teman }\end{array}$ & 33 & 31 & 94,3 & 88,6 & & \\
\hline \multirow{2}{*}{$\begin{array}{l}\text { Writing } \\
\text { activities }\end{array}$} & $\begin{array}{l}\text { Mengisi bagian yang kosong dari LKPD } \\
\text { berbentuk komik }\end{array}$ & 34 & 32 & 97,1 & 91,4 & \multirow[t]{2}{*}{98,57} & \multirow[t]{2}{*}{95,71} \\
\hline & Mengerjakan semua soal tes evaluasi & 35 & 35 & 100,0 & 100,0 & & \\
\hline \multicolumn{6}{|c|}{ Rata-rata persentase aktivitas belajar peserta didik } & 89,37 & 89,33 \\
\hline
\end{tabular}


Keterangan: $\quad \mathrm{P} 1=$ pertemuan 1

$\mathrm{P} 2=$ pertemuan 2

Berdasarkan tabel 1, persentase aktivitas belajar peserta didik pertemuan pertama untuk kategori visual activities sebesar 96,43\%, oral activities sebesar 77,71\%, listening activities sebesar 84,76\%, dan writing activities sebesar 98,57\%. Rata-rata persentasenya adalah $89,37 \%$ yang artinya, aktivitas belajar peserta didik pada pertemuan pertama termasuk dalam kategori "sangat aktif". Sedangkan pada pertemuan kedua untuk kategori visual activities sebesar $87,14 \%$, oral activities sebesar $86,86 \%$, listening activities sebesar 87,62\%, dan writing activities sebesar 95,71\%. Rata-rata persentasenya adalah $89,33 \%$ yang artinya, aktivitas belajar peserta didik pada pertemuan kedua termasuk dalam kategori "sangat aktif". Rata-rata persentase aktivitas belajar peserta didik untuk dua pertemuan adalah 89,35\%. Maka, dapat disimpulkan bahwa aktivitas belajar peserta didik selama pembelajaran matematika menggunakan LKPD berbentuk komik pada materi Matriks tergolong ke dalam kategori "sangat aktif".

Data tes hasil belajar didapat setelah diberikan dua kali pembelajaran matematika menggunakan LKPD berbentuk komik. Data kemudian diolah dengan memberi skor pada setiap jawaban peserta didik, kemudian skor tersebut diubah ke dalam bentuk nilai berskala 1-100. Setelah diolah, didapatlah sebanyak 30 peserta didik tuntas karena memperoleh nilai $\geq 76$ dan lima peserta didik tidak tuntas karena memperoleh nilai $<76$. Persentase peserta didik yang tuntas adalah $85,7 \%$ dan yang tidak tuntas adalah 14,3\%. Persentase dapat dilihat pada gambar 1 berikut.

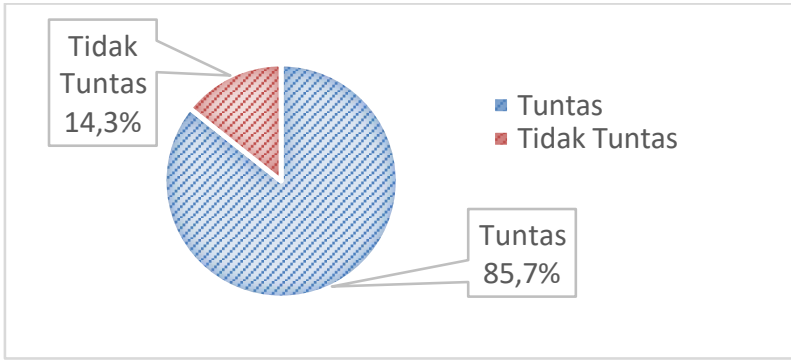

Gambar 1. Diagram Persentase Nilai Tes Hasil Belajar Peserta Didik

Angket respons peserta didik diberikan setelah proses pembelajaran dan juga setelah mengerjakan soal tes hasil belajar. Hasil perolehan data angket respons peserta didik terhadap pembelajaran diolah dan dianalisis menggunakan perhitungan skala likert. Dari perhitungan deviasi normal, diperolehlah nilai skala dari tiap butir pernyataan. Lalu dihitung bobot skala tiap kategori respons peserta didik dan dirataratakan. Diperolehlah penggarisan yang berfungsi sebagai panduan dalam menginterpretasikan respons peserta didik terhadap pembelajaran sebagai berikut.

\begin{tabular}{|c|c|c|c|c|}
\hline SN & \multicolumn{2}{|l|}{$\mathbf{N}$} & $\mathbf{P}$ & SP \\
\hline 0 & 0,051 & & 0,498 & 1,937 \\
\hline & & 0,249 & & \\
\hline
\end{tabular}


Berdasarkan penggarisan tersebut, interval respons peserta didik terhadap pembelajaran matematika tergambar jelas melalui Tabel 3 berikut.

Tabel 3. Respons Peserta Didik Terhadap Pembelajaran

\begin{tabular}{cc}
\hline Interval & Kategori \\
\hline $0 \leq x \leq 0,025$ & Sangat Negatif \\
\hline $0,025<x \leq 0,249$ & Negatif \\
\hline $0,249<x \leq 0,968$ & Positif \\
\hline$x>0,968$ & Sangat Positif \\
\hline
\end{tabular}

Berdasarkan tabel di atas, respons peserta didik terhadap pembelajaran matematika menggunakan LKPD berbentuk komik pada materi operasi matriks dapat diklasifikasikan sebagai berikut.

Tabel 4. Klasifikasi Respons Peserta Didik Terhadap Pembelajaran

\begin{tabular}{|c|c|c|c|}
\hline No. & Kode Peserta didik & Rata-rata Skor & Kategori \\
\hline 1 & AAL & 1,664 & Sangat Positif \\
\hline 2 & AMS & 1,662 & Sangat Positif \\
\hline 3 & $\mathrm{AS}$ & 1,847 & Sangat Positif \\
\hline 4 & ATP & 1,856 & Sangat Positif \\
\hline 5 & BAP & 1,247 & Sangat Positif \\
\hline 6 & DIP & 0,960 & Positif \\
\hline 7 & DR & 1,341 & Sangat Positif \\
\hline 8 & EI & 1,066 & Sangat Positif \\
\hline 9 & IBW & 1,059 & Sangat Positif \\
\hline 10 & $\mathrm{LF}$ & 1,840 & Sangat Positif \\
\hline 11 & LW & 1,843 & Sangat Positif \\
\hline 12 & MA & 1,110 & Sangat Positif \\
\hline 13 & MAFA & 0,340 & Positif \\
\hline 14 & MAP & 1,337 & Sangat Positif \\
\hline 15 & MDA & 0,535 & Positif \\
\hline 16 & MFI & 1,525 & Sangat Positif \\
\hline 17 & MFRAA & 1,525 & Sangat Positif \\
\hline 18 & MKA & 1,197 & Sangat Positif \\
\hline 19 & NFF & 1,021 & Sangat Positif \\
\hline 20 & NHP & 1,756 & Sangat Positif \\
\hline 21 & NW & 1,063 & Sangat Positif \\
\hline 22 & OAM & 1,574 & Sangat Positif \\
\hline 23 & OSI & 1,523 & Sangat Positif \\
\hline 24 & PA & 0,648 & Positif \\
\hline 25 & $\mathrm{R}$ & 0,876 & Positif \\
\hline 26 & $S$ & 1,937 & Sangat Positif \\
\hline 27 & $\mathrm{SC}$ & 1,021 & Sangat Positif \\
\hline 28 & SD & 0,399 & Positif \\
\hline 29 & SEB & 1,368 & Sangat Positif \\
\hline 30 & SR & 1,621 & Sangat Positif \\
\hline 31 & SST & 1,796 & Sangat Positif \\
\hline 32 & SW & 1,937 & Sangat Positif \\
\hline 33 & TKT & 1,663 & Sangat Positif \\
\hline 34 & UR & 1,892 & Sangat Positif \\
\hline \multirow[t]{2}{*}{35} & YA & 1,481 & Sangat Positif \\
\hline & Rata-rata & 1,358 & Sangat Positif \\
\hline
\end{tabular}

Tabel 5. Persentase Respons Peserta Didik dalam Pembelajaran 


\begin{tabular}{ccc}
\hline Kategori & $\boldsymbol{\Sigma}$ Peserta Didik & $\boldsymbol{\%}$ \\
\hline Sangat Positif & 29 & $82,86 \%$ \\
\hline Positif & 6 & $17,14 \%$ \\
\hline Negatif & 0 & $0 \%$ \\
\hline Sangat Negatif & 0 & $0 \%$ \\
\hline Jumlah & 35 & $100 \%$
\end{tabular}

Berdasarkan Tabel 4 terlihat bahwa skor rata-rata respons peserta didik terhadap pembelajaran matematika menggunakan LKPD berbentuk komik adalah 1,358 dan tergolong dalam kategori "sangat positif'. Tabel 5 juga menjelaskan bahwa sebanyak 29 peserta didik atau 82,86\% peserta didik tergolong dalam kategori respons "sangat positif" dan sebanyak enam peserta didik atau 17,14\% peserta didik tergolong dalam kategori respons "positif".

Observasi keterlaksanaan pengelolaan pembelajaran oleh guru dilakukan dua kali. Masing-masing pertemuan dilakukan pengamatan terhadap keterlaksanaan kegiatan pembelajaran yang telah direncanakan dalam RPP. Pengamatan dilakukan oleh seorang guru matematika SMAN 3 Pontianak. Hasil pengamatan yang dianalisis dan diperoleh data sebagai berikut.

Tabel 6. Deskripsi Hasil Observasi Keterlaksanaan Pengelolaan Pembelajaran oleh Guru

\begin{tabular}{lcc}
\hline \multirow{2}{*}{ Uraian } & \multicolumn{2}{c}{ Keterlaksanaan } \\
\cline { 2 - 3 } & Pertemuan 1 & Pertemuan 2 \\
\hline Jumlah langkah yang terlaksana & 22 dari 22 langkah & 22 dari 22 langkah \\
\hline Persentase keterlaksanaan & $100 \%$ & $100 \%$ \\
\hline
\end{tabular}

Tabel 7. Deskripsi Penilaian Hasil Observasi Keterlaksanaan Pengelolaan Pembelajaran oleh Guru

\begin{tabular}{cccccc}
\hline \multirow{2}{*}{ No. } & \multirow{2}{*}{ Kegiatan } & \multicolumn{2}{c}{ Pertemuan 1 } & \multicolumn{2}{c}{ Pertemuan 2 } \\
\cline { 3 - 6 } & & Rata-rata & Keterangan & Rata-rata & Keterangan \\
\hline 1 & Pendahuluan & 3,50 & Sangat Baik & 3,75 & Sangat Baik \\
\hline 2 & Inti & 3,44 & Baik & 3,44 & Baik \\
\hline 3 & Penutup & 4,00 & Sangat Baik & 3,80 & Sangat Baik \\
\hline & Rata-rata & 3,65 & Sangat Baik & 3,66 & Sangat Baik \\
\hline
\end{tabular}

Tabel 6 menunjukkan bahwa secara keseluruhan langkah-langkah pembelajaran yang telah direncanakan dalam RPP terlaksana dengan persentase keterlaksanaan $100 \%$. Tabel 7 menunjukkan bahwa rata-rata hasil penilaian keterlaksanaan pengelolaan pembelajaran oleh guru pada pertemuan ke-1 sebesar 3,65 dan pada pertemuan ke-2 sebesar 3,66. Rata-rata hasil penilaian keterlaksanaan pengelolaan pembelajaran oleh guru untuk dua pertemuan adalah 3,655. Maka, dapat disimpulkan bahwa keterlaksanaan pengelolaan pembelajaran oleh guru dalam pembelajaran menggunakan LKPD berbentuk komik pada materi matriks di Kelas XI IPA 2 SMAN 3 Pontianak termasuk dalam kategori 'sangat baik'.

\subsection{Pembahasan}

Pembelajaran pada penelitian ini dilaksanakan sebanyak dua kali pertemuan dengan menggunakan media berupa LKPD berbentuk komik pada materi Operasi Matriks, di Kelas XI IPA 2 SMAN 3 Pontianak. Kegiatan pembelajaran diikuti oleh 35 peserta didik.

Pembelajaran berjalan sesuai dengan Rencana Pelaksanaan Pembelajaran (RPP) yang telah dibuat. Peserta didik terlihat antusias dalam diskusi kelompok, membaca 
jalan cerita komik, memahami materi, mengisi LKPD, hingga mengomunikasikan hasil diskusi ke depan Kelas. Sedangkan keterlaksanaan peneliti mengelola pembelajaran di observasi oleh seorang guru matematika SMAN 3 Pontianak dengan berdasar pada lembar observasi yang telah dibuat. Aktivitas yang dilakukan oleh peserta didik selama proses pembelajaran berlangsung juga diobservasi oleh dua orang mahasiswa prodi pendidikan matematika.

Persentase aktivitas belajar peserta didik berdasarkan empat kategori adalah sebagai berikut: (1) kategori visual activities pertemuan ke-1 adalah sebesar 96,43\% dan $87,14 \%$ dipertemuan ke-2. Sehingga rata-rata persentasenya adalah sebesar 91,79\% dan tergolong dalam kategori 'sangat aktif'; (2) kategori oral activities pertemuan ke-1 adalah sebesar $77,71 \%$ dan $88 \%$ dipertemuan ke-2. Sehingga rata-rata persentasenya adalah sebesar $82,86 \%$ dan tergolong dalam kategori 'sangat aktif'; (3) kategori listening activities dipertemuan ke-1 adalah sebesar 84,76\% dan 87,62\% dipertemuan ke-2. Sehingga rata-rata persentasenya adalah sebesar $86,19 \%$ dan tergolong dalam kategori 'sangat aktif'; (4) kategori writing activities pertemuan ke-1 adalah sebesar 98,57\% dan 95,71\% dipertemuan ke-2. Sehingga rata-rata persentasenya adalah sebesar $97,14 \%$ dan tergolong dalam kategori 'sangat aktif'. Dari semua kategori aktivitas belajar peserta didik, terlihat bahwa persentase aktivitas belajar peserta didik yang paling rendah adalah pada kategori oral activities, yaitu sebesar $82,86 \%$ dan yang paling tinggi adalah kategori writing activities, yaitu sebesar 97,14\%.

Berdasarkan data pengamatan aktivitas belajar peserta didik terlihat bahwa rata-rata persentase aktivitas belajar peserta didik pertemuan pertama adalah $89,37 \%$ dan pada pertemuan kedua adalah $89,62 \%$ sehingga dapat digolongkan dalam kategori 'sangat aktif'.

Hasil penskoran dan penilaian tes hasil belajar menunjukkan bahwa 30 peserta didik mendapatkan nilai lebih dari atau sama dengan KKM dan lima peserta didik mendapatkan nilai kurang dari KKM. Hasil tersebut menunjukkan persentase jumlah peserta didik yang tuntas sebesar $85,7 \%$ dan yang tidak tuntas sebesar $14,3 \%$. Karena persentase peserta didik yang tuntas adalah $85,7 \%$, yang berarti lebih dari $80 \%$, maka dapat disimpulkan bahwa ketuntasan hasil belajar peserta didik secara klasikal terpenuhi.

Angket respons peserta didik berisi 30 pertanyaan yang terdiri dari pernyataan positif dan negatif. Hasil perhitungan angket respons peserta didik terhadap pembelajaran matematika menggunakan LKPD berbentuk komik pada materi operasi matriks, terdapat 29 peserta didik yang memiliki respons sangat positif atau sebesar $82,86 \%$ dan enam peserta didik memiliki respons positif atau sebesar 17,14\%. Rata-rata skor respons peserta didik satu kelas adalah sebesar 1,358 dan tergolong ke dalam kategori "sangat positif". Hal ini berarti respons 35 orang peserta didik Kelas XI IPA 2 SMAN 3 Pontianak secara umum, terhadap pembelajaran matematika menggunakan LKPD berbentuk komik pada materi operasi matriks tergolong "sangat positif".

Data keterlaksanaan pengelolaan pembelajaran oleh guru (peneliti) didapat setelah pembelajaran pertama dan kedua terlaksana. Pada pertemuan pertama, rata-rata 
penilaian keterlaksanaan pengelolaan pembelajaran oleh guru di kegiatan pendahuluan sebesar 3,50 dan tergolong dalam kategori 'sangat baik', di kegiatan inti sebersar 3,44 dan tergolong dalam kategori 'baik', serta di kegiatan penutup sebesar 4 dan tergolong dalam kategori 'sangat baik'. Sedangkan pada pertemuan kedua, rata-rata penilaian keterlaksanaan pengelolaan pembelajaran oleh guru di kegiatan pendahuluan sebesar 3,75 dan tergolong dalam kategori 'sangat baik', di kegiatan inti sebersar 3,44 dan tergolong dalam kategori 'baik', serta di kegiatan penutup sebesar 3,80 dan tergolong dalam kategori 'sangat baik'.

Rata-rata penilaian keterlaksanaan pengelolaan pembelajaran oleh guru pertemuan pertama sebesar 3,65 dengan kategori sangat baik dan pertemuan kedua sebesar 3,66 dengan kategori sangat baik pula. Rata-rata penilaian keterlaksanaan pengelolaan pembelajaran oleh guru pertemuan pertama dan kedua adalah 3,655 dan tergolong dalam kategori 'sangat baik'. Hal ini dikarenakan perangkat pembelajaran seperti RPP dan LKPD berbentuk komik sudah dipersiapkan sesuai dengan rancangan yang telah dibuat dan telah melalui tahap validasi oleh beberapa validator. Observasi terhadap guru saat di lapangan juga berjalan dengan baik. Antusias dan aktifnya peserta didik saat pembelajaran menggunakan LKPD berbentuk komik diberikan juga membuat peneliti mudah untuk mengelola Kelas. Oleh karena peneliti juga sudah kenal dengan karakter peserta didik, hal ini memudahkan peneliti untuk mengambil perhatian peserta didik, mengatur peserta didik, serta mengelola pembelajaran secara keseluruhan.

Efektivitas pembelajaran matematika menggunakan LKPD berbentuk komik pada materi operasi matriks ditinjau dari empat aspek, yaitu: (1) aktivitas belajar peserta didik; (2) hasil belajar peserta didik; (3) respons peserta didik; dan (4) keterlaksanaan pengelolaan pembelajaran oleh guru. Pembelajaran matematika menggunakan LKPD berbentuk komik dalam penelitian ini dikatakan efektif jika keempat aspek indikator efektivitas di atas telah terpenuhi.

Hasil analisis data yang diperoleh dari keempat indikator keefektifan pembelajaran yang telah dipaparkan di atas terlihat bahwa keempat indikator efektivitas terpenuhi, yaitu: (1) rata-rata aktivitas belajar peserta didik yang diperoleh sebesar 89,5\% dan berada antara interval persentase $75 \%$ sampai $100 \%$. sehingga aktivitas belajar peserta didik tergolong ke dalam kategori 'sangat aktif'; (2) jumlah peserta didik yang tuntas dalam mengerjakan tes hasil belajar sebesar $88 \%$, sehingga hasil belajar peserta didik tuntas secara klasikal karena $\geq 80 \%$ peserta didik memperoleh nilai tes hasil belajar $\geq$ 76; (3) terdapat 29 peserta didik yang memiliki respons sangat positif atau sebesar $82,86 \%$ dan enam peserta didik memiliki respons positif atau sebesar 17,14\%, serta rata-rata skor respons peserta didik satu kelas adalah sebesar 1,358. Oleh karena itu, respons peserta didik tergolong ke dalam kategori 'sangat positif'; dan (4) rata-rata penilaian keterlaksanaan pengelolaan pembelajaran oleh guru dalam pembelajaran menggunakan LKPD berbentuk komik adalah 3,655 dan tergolong dalam kategori 'sangat baik'. Oleh karena keempat aspek indikator efektivitas terpenuhi, maka dapat disimpulkan bahwa pembelajaran matematika menggunakan LKPD berbentuk komik pada materi operasi matriks di Kelas XI IPA 2 SMAN 3 Pontianak efektif. 


\section{Kesimpulan dan Saran Kesimpulan}

Dari paparan hasil penelitian di atas disimpulkan bahwa pembelajaran matematika menggunakan LKPD berbentuk komik efektif diterapkan pada materi operasi matriks di Kelas XI IPA 2 SMAN 3 Pontianak. Hal ini dikarenakan terpenuhinya keempat aspek indikator efektivitas pembelajaran, yaitu: (1) aktivitas belajar peserta didik pada pembelajaran matematika menggunakan LKPD berbentuk komik materi operasi matriks tergolong dalam kategori 'sangat aktif', dengan rata-rata aktivitas belajar peserta didik yang diperoleh sebesar 89,35\%, (2) hasil belajar peserta didik tuntas secara klasikal karena $\geq 80 \%$ peserta didik memperoleh nilai tes hasil belajar $\geq 76$, yaitu $88 \%$ peserta didik tuntas dalam mengerjakan tes hasil belajar, (3) peserta didik memberikan respons "sangat positif" terhadap pembelajaran matematika menggunakan LKPD berbentuk komik pada materi operasi matriks, dengan rata-rata skor respons peserta didik satu kelas adalah sebesar 1,358, dan (4) keterlaksanaan pengelolaan pembelajaran oleh guru dalam pembelajaran matematika menggunakan LKPD berbentuk komik materi operasi matriks tergolong dalam kategori 'sangat baik', dengan rata-rata penilaian keterlaksanaan pembelajaran sebesar 3,655.

\section{Saran}

Berdasarkan keterbatasan yang ditemui di lapangan saat penelitian, ada beberapa saran yang perlu peneliti sampaikan, yaitu: (1) untuk peneliti lain yang ingin menindaklanjuti penelitian ini, sebaiknya lebih mengonsepkan lagi perubahan sistem tempat duduk peserta didik saat pembelajaran berlangsung, dari yang awalnya duduk sesuai tempat duduk masing-masing (sebelum diskusi kelompok) menjadi duduk secara berkelompok kecil. Hal ini perlu dilakukan agar tidak membingungkan observer dalam mengamati aktivitas belajar peserta didik, (2) untuk peneliti lain, sebaiknya memikirkan waktu yang tepat saat melakukan penelitian. Memulai pembelajaran pada pagi hari cukup efektif dilakukan karena peserta didik masih segar dan bersemangat untuk mengikuti pembelajaran.

\section{Referensi}

Amirudin, Wildan. 2016. Meningkatkan Aktivitas Belajar Siswa Menggunakan Teknik Mind Mapping pada Mata Pelajaran IPA Kelas V. Jurnal Pendidikan Guru Sekolah Dasar Edisi 26. (5): 2547-2552.

Azwar, Saifuddin. 1995. Sikap Manusia, Edisi 2. Yogyakarta: Pustaka Pelajar.

Basuni, Bistari. (2017). Konsep dan Indikator Pembelajaran Efektif: Jurnal Kajian Pembelajaran dan Keilmuan. Pontianak: FKIP UNTAN.

Haran, A., Hartoyo, A., \& Sayu, S. (2019). Etnomatematika Dalam Merangkai Manik Masyarakat Dayak Kayaan Kapuas Hulu. Jurnal Pendidikan Dan Pembelajaran ..., 8(3), 1-8. https://jurnal.untan.ac.id/index.php/jpdpb/article/view/31952

Jamiah, Y. (2020). Penguatan Karakter Siswa Perbatasan Melalui Internalisasi Kearifan Lokal Dalam Pembelajaran Matematika. Jurnal AlphaEuclidEdu, 1(2), 69. https://doi.org/10.26418/ja.v1i2.43306 
Muzaini, Muhammad. 2016. Efektivitas Metode The Learning Cell dalam Pembelajaran Matematika pada Siswa Kelas VIII SMP Negeri 4 Sungguminasa Kabupaten Gowa. Prosiding Seminar Nasional ISSN 2443-1109. 2 (1): 590-598.

Nawawi, Hadari. 2015. Metode Penelitian Bidang Sosial. Yogyakarta: Gajah Mada University Press.

Nurdin, S. dan Adriantoni. 2016. Kurikulum dan Pembelajaran. Jakarta: PT Rajagrafindo Persada.

Pitadjeng. 2015 Pembelajaran Matematika yang Menyenangkan. Yogyakarta: Graha Ilmu.

Riduwan. 2015. Dasar-Dasar Statistika. Bandung: Alfabeta.

Sengüla, Sare dan Ilker Üner.2010. What is the impact of the teaching "Algebraic Expressions and Equations" topic with concept cartoons on the students' logical thinking abilities?.Elsevier. 2: 5441- 5445.

Sudijono, Anas. 2012. Pengantar Evaluasi Pendidikan. Jakarta: PT. Raja Grafindo Persada.

Sugiyono. 2016. Metode Penelitian Pendidikan. Bandung: Alfabeta.

Sumiati dan Asra. 2007. Metode Pembelajaran. Bandung: CV Wacana Prima.

Susanti,K.D., Subiki, dan Yushardi. 2016. Pengembangan Lembar Kerja Siswa (LKS) disertai Komik Fisika pada Pembelajaran Pokok Bahasan Tekanan di SMP. Jurnal Pembelajaran Fisika. 5 (3):197-204.

Utomo, Prasetyo Eko. 2012. Pengembangan Lembar Kerja Siswa dengan Media Ilustrasi Komik. Surakarta:Tesis.

Widjajanti, Endang. 2008. Kualitas Lembar Kerja Siswa. Makalah dalam Kegiatan Pengabdian pada Masyarakat dengan judul "Pelatihan Penyusunan LKS Mata Pelajaran Kimia Berdasarkan Kurikulum Tingkat Satuan Pendidikan Bagi Guru SMK/MAK"di Ruang Sidang Kimia FMIPA UNY.

Windayana H., Priatna D., dan Kartika E. 2013. Penggunaan Lembar Kerja Seting Komik dalam Meningkatkan Prestasi Belajar Matematika Siswa Sekolah Dasar. EduHumaniora. 5 (2): 101-106. 